\title{
Impact on the Abandonment of Semi-Natural Grasslands from Apuseni Mountains
}

\author{
Ioana VAIDA, Ioan ROTAR, Florin PĂCURAR*, Roxana VIDICAN, Anca PLEŞA, Anamaria MĂLINAŞ, Vlad \\ STOIAN
}

${ }^{1}$ Faculty of Agriculture, Department of Plant Crops. University of Agricultural Sciences and Veterinary Medicine Cluj-Napoca, Manăștur street, 3-5, 400372, Romania

*corresponding author: fpacurar@gmail.com

Bulletin UASVM series Agriculture 73(2)/2016

Print ISSN 1843-5246; Electronic ISSN 1843-5386

DOI 10.15835/buasvmcn-agr: 12417

\begin{abstract}
According to The European Communion in Europe there are large areas of abandoned grasslands (Osterburg and colab., 2010). The abandonment of grasslands entails substantial changes to the vegetation cover. Usually, after a period of time, semi-natural grasslands start to develop forestlike features. In Romania despite the existence of a subsidiary system large areas with semi-natural grasslands are abandoned. The objective of this paper was to analyze the effect of abandonment on the structure of vegetation cover. The experiment consists in 3 experimental variants ( 1 mowed annually, 1 abandoned for 5 years and 1 abandoned for 15 years) and is located in the village of Ghețari, from Gârda de Sus commune at an altitude of $1130 \mathrm{~m}$. Vegetation was studied using the Braun-Blanquet method, modified by Păcurar and Rotar in 2014. The scientific results were processed with the numerical analysis application (Cluster Analyses) belonging to PC-ORD program. Results showed that the grassland abandoned for 5 years did not show any statistical difference compared to the grassland mowed annually. The grassland abandoned for 15 years showed modification in the structure of vegetation cover translated by the disappearance of numerous species.Our reccomandation is that semi-natural grasslands, which have numerous economical disadvantages because of their location, should be mowed at least every five years.
\end{abstract}

Keywords: grasslands, abandonment, vegetational cover.

\section{INTRODUCTION}

Grassland is a major resource of life biosphere that sustains approximately one billion people worldwide (Schnyder et al., 2010). Semi-natural grasslands grow naturally in places where woody vegetation doesn't meet the required ecological conditions to install and develop. Inadequate conditions for forests are found in places where the average annual temperature is too low, on salty soils, on areas too wet or too dry for forests to install, on soils rich in heavy metals, on slopes with high dynamic erosion (clay soils, sandy soils) or steep cliffs, which do not form a sufficient ground. Savannahs and steppes represent phytogeographic formations of the largest areas occupied by grasslands (Stugren, 2011). By an abandoned agricultural land we generally understand an un- cultivated land which evolved to fallow if we speak about arable land or an ungrazed of unmowed land which evolved to shrubs or even forest in the case of grasslands (Marușca, 2012). The permanent pastures which are ussualy abandoned or neglected will finally be invaded by woody species, expressing their natural return to forest vegetation from which they evolved after deforestation and management with animals (Marușca, 2010). The abandonment of arable land is followed, in all cases, by an excessive weed growth, which are first composed by annual plants and finally by perennial plant species including fallow land. Unvalorization of grass vegetation from former arable land will lead to the installation and expansion of woody vegetation and even into forest areas (Marușca, 2012). 
The abandonment of seminatural grassland has become a major threat and raises a number of questions and situations to be resolved all across Europe (Osterburg et al., 2010). Grasslands habitats located in mountainous areas are very vulnerable and lose very quickly their conservation value after their abandonment (Fischer and Wipf, 2002). In these areas secondary succession occur translated at first as changes in the floristic composition specific to one area (Habel et al., 2013). Sometimes changes can be so obvious that they are threatening even grassland ecosystem integrity (Kryszak et al., 2012). The restoration of a grassland ecosystem at the initial stage could be a very long and almost impossible process (Galvanek and Leps, 2012). After 1990 our country recorded a progressive and generalized abandonment of mountain pastures. Some people believe that this is due to the halving number of cattle and sheep from the last two decades and especially to the use of the reserve feed provided by arable land in the hilly and plain areas left fallow on the premises stretched more easily accessible, with conditions much more good living for carers and without danger of having damage caused by wild animals prey or phenomenal nature of the mountains, which are much tougher. The abandonment of mountain meadows produce great losses in the national economy for at least two important reasons:

- irrecoverable loss of free solar energy stored in the grassy carpet of meadow as they convert organic material susceptible to the animal by products useful to man (milk, meat, driving force, leisure etc.);

- underflow to abandonent, followed by the return to the former locations of woody vegetation, the hedges and woods, with generations of mountaineers have struggled to maintain grasslands in the state of normality livestock (Marușca, 2010).

Abandonment of grasslands is a problem in the Apuseni Mountains. It suggests a rotational pasture management and the various stages, before reaching the stage of mature forest. This could be achieved by supporting traditional production and maintaining grassland stages with subsidies from the government and / or private organizations. A similar approach has been proposed for semi-natural grasslands nutrient poor in Central Europe (Duffey et al., 1974; Morris and Thomas, 1991; Erhardt, 1995; Dzwonko and Loster, 1998; Waldhardt and Otte, 2003). This approach requires a specific management plan to prevent the loss of unique species (Thomas, $1984,1991)$. Regarding the changes that occur in the grassy carpet after abandonment and further study the floristic composition of secondary meadows in various stages of succession it was found that the categories of abandonment caused changes in the phytocoenoses. They recorded a grassy carpet degradation both in terms of agronomic and ecological especially phytocoenosis abandoned over 10 years. It has been proven that abandonment frequently leads to a decrease in the number of species and only a few of which are dominant (Tasser and Tappeiner, 2002; Willems, 1983; Maskova Z et al., 2009). Total lack of maintenance of grasslands is reflected by the presence of molehills that degrades especially fallow pastures resulting in decreased production due to deterioration of its quality increases worthless vegetation on anthills (Thymus species, Rumex acetosella etc.). On hampers mowing meadows influencing the quantity and quality of hay obtained. Can be formed mounds of moles (return places), ants (often in the mountains), but may have their origin and bushes (death) of some grasses and sedges of dense bush (Deschampsia caespitosa, Juncus species). Sometimes forms on stumps, rocks or by the accumulation of organic matter plant (mosses, lichens), especially in the lower areas in the mountains (Rotar and Păcurar, 2011). The primary objective of the study is tracking the effect of abandonment on the grassy carpet structure.

\section{MATERIALS AND METHODS}

To determine the abundance dominance we used Braun-Blanquet scale, modified Păcurar and Rotar in 2014. To assess the agronomic value of meadows, the scale intervals are too broad and too remote central difference values. Often the agronomic value measured on the basis of collected data on the Braun-Blanquet scale (although improvements) is far from reality. The authors quoted above have proposed using three sub-scale scores and three sub-intervals with corresponding core values (Tab. 1., Fig. 1.). 
Tab. 1. Scale of assessment of dominance Braun-Blanquet abundance, complemented Tüxen and Ellenberg (1937), modified with three sub-grades and three sub-intervals

\begin{tabular}{|c|c|c|c|c|c|}
\hline Note & $\begin{array}{l}\text { The range of } \\
\text { coating }\end{array}$ & $\begin{array}{l}\text { The central } \\
\text { value of the } \\
\text { class }\end{array}$ & Under-note & Under -ranges (\%) & $\begin{array}{l}\text { Central value } \\
\text { adjusted below the } \\
\text { range (\%) }\end{array}$ \\
\hline \multirow{3}{*}{5} & \multirow{3}{*}{$75-100$} & \multirow{3}{*}{87,5} & $5 c$ & $92-100$ & 96 \\
\hline & & & $5 b$ & $83-92$ & 87,5 \\
\hline & & & $5 a$ & $75-83$ & 79 \\
\hline \multirow{3}{*}{4} & \multirow{3}{*}{$50-75$} & \multirow{3}{*}{62,5} & $4 \mathrm{c}$ & $67-75$ & 71 \\
\hline & & & $4 \mathrm{~b}$ & $58-67$ & 62,5 \\
\hline & & & $4 a$ & $50-58$ & 54 \\
\hline \multirow{3}{*}{3} & \multirow{3}{*}{$25-50$} & \multirow{3}{*}{37,5} & $3 c$ & $42-50$ & 46 \\
\hline & & & $3 b$ & $33-42$ & 37,5 \\
\hline & & & $3 a$ & $25-33$ & 29 \\
\hline \multirow{3}{*}{2} & \multirow{3}{*}{$10-25$} & \multirow{3}{*}{17,5} & $2 c$ & $20-25$ & 22,25 \\
\hline & & & $2 b$ & $15-20$ & 17,5 \\
\hline & & & $2 \mathrm{a}$ & $10-15$ & 12,5 \\
\hline \multirow{3}{*}{1} & \multirow{3}{*}{$1-10$} & \multirow{3}{*}{5} & $1 \mathrm{c}$ & $6-10$ & 8 \\
\hline & & & $1 \mathrm{~b}$ & $4-6$ & 5 \\
\hline & & & $1 \mathrm{a}$ & $1-4$ & 2,5 \\
\hline+ & $0,1-1$ & 0,5 & - & - & 0,5 \\
\hline $\mathbf{R}$ & $0,01-0,1$ & 0,05 & - & - & 0,05 \\
\hline
\end{tabular}
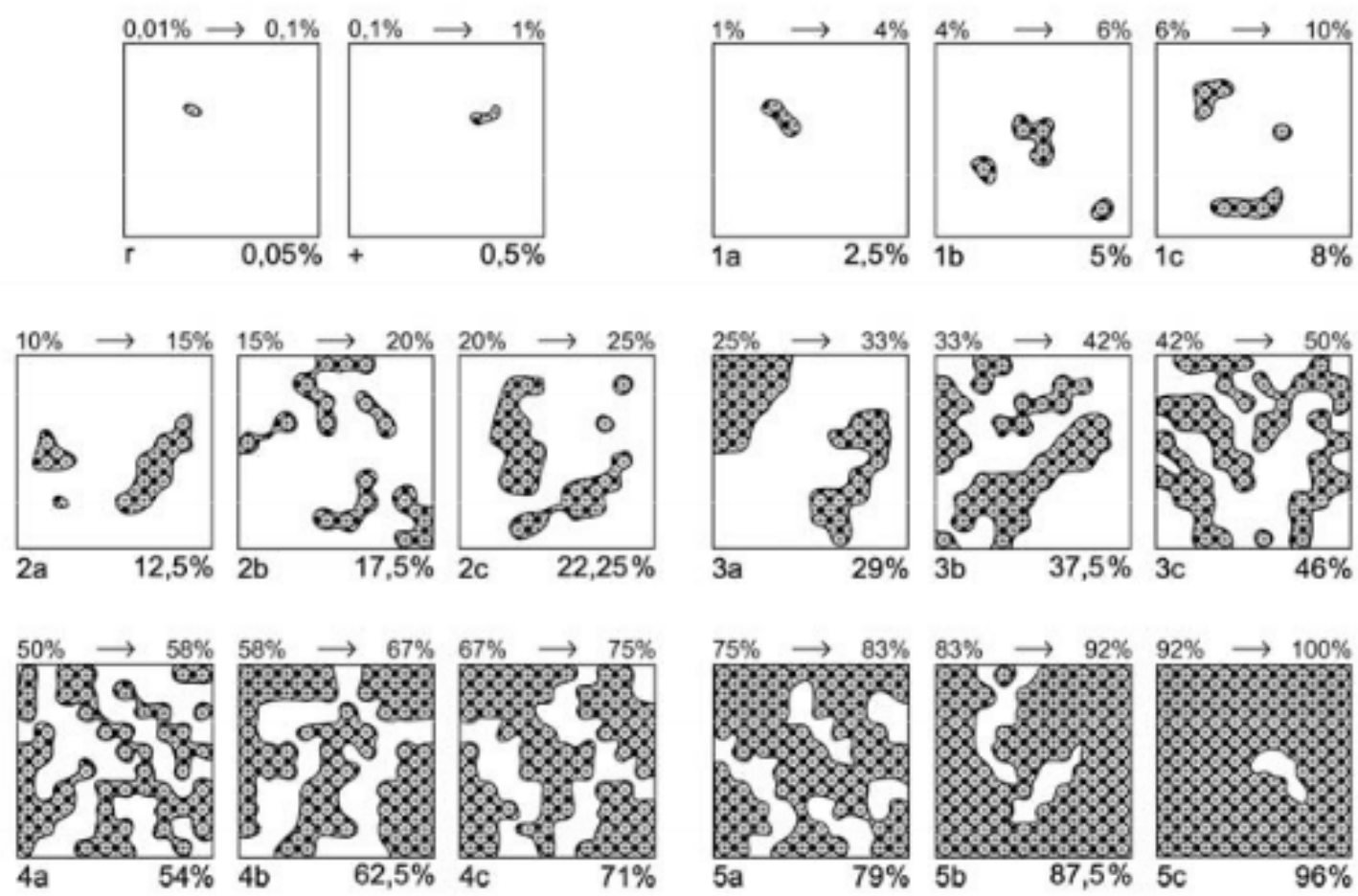

Fig. 1. Scheme appreciation of abundance dominance after Braun-Blanquet method, using three sub-grades (Păcurar and Rotar, 2014) 


\section{RESULTS AND DISCUSSION}

The results were classified after Sorensen index (Bray and Curtis) associated with average connection. PC-ORD program revealed the dendrogram presented in Fig. 2 which highligts how the joins of reports and the distance between variants. A highly debated topic within experts in the field is the level where we should cut off the dendogram to determine the optimal number of groups. There are several theories in literature but none is universally accepted. Kent (2012) recommends cutting to a higher level dendogram torso, which groups results show a justified sense phytosociological and ecological (Păcurar and Rotar, 2014)

The classification of vegetation made in PCORD revealed two groups of plants (Fig. 2). Is observed that the first two variants, namely the grassland mowed annually (V1) and the one abandoned for 5 years (V2) did not show significant changes in the grassy carpet, being very similar one to each other (red) .
Compared with the first the second group (coloured in green) differs in terms of flora. In other words floristic distance between the two groups is high and presents statistical backing ( $\mathrm{p} \leq 0.05$ ).

An other method we used is the dual classification, which enables concurrent group of reports and both species (Fig. 3). Numerical analysis with a dual classification pointed out certain groups of species. On the dendrogram presented in Fig. 3 we observed that there are species that are common to all treatments and some species occur only in certain types of management.

The test of distance between groups resulting from the ordering process was done with multiple response permutation (MRPP). MRPP is a nonparametric procedure for testing the null hypothesis of difference (null hypothesis) between two or more groups (McCune and Mefford, 2011). In our case we compared the floristic composition of the grassland mowed annually with the grassland abandoned for 5 years and for 15 years.

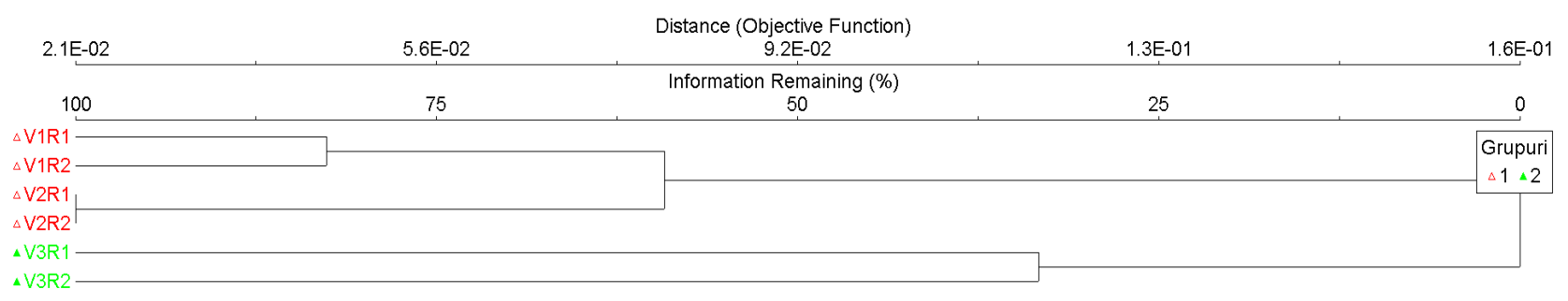

Fig. 2. Dendrogram classification of reports

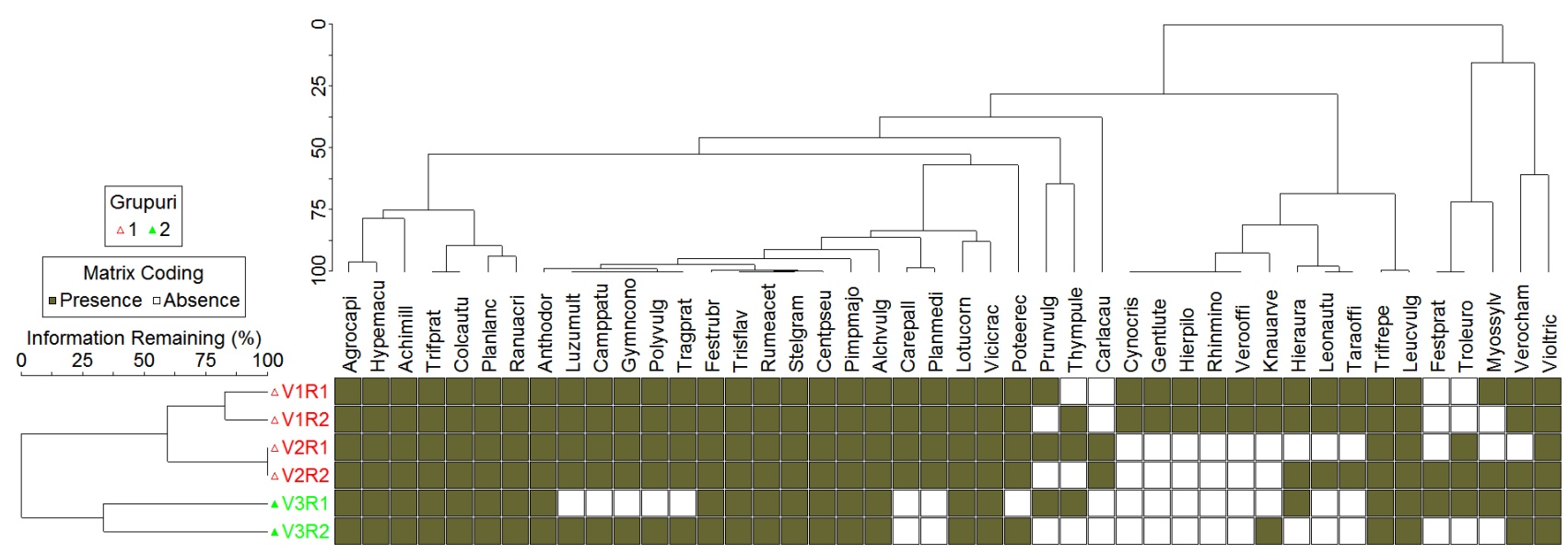

Fig. 3 Dendrogram classification of reports 
MRPP statistical method involves the use of $\mathrm{T}$ test which describes the separation between groups. When T is negative the separation is stronger; 0 hypothesis assumes that land abandonment has no effect on the grassy carpet. Multiple response permutation procedure shows that the hypothesis 0 is not true, because the test has a value of $-1.7991231 \mathrm{~T}$ therefore we can say that early experience changes statistically on the grassy carpet.
A statistical test described homogeneity / heterogeneity between groups. When all groups are identical A will be equal to one, and if they are very different, it will be zero. A statistical test has a value of 0.09284809 approaching zero, therefore it can be said that the groups are different.

Testing groups resulting from cluster analysis can be done using analysis of indicator species. Indicator species analysis of the three experimental variants showed the presence of 8 species indicator (Tab. 2).

Tab. 2. Indicator species compared with the experimental variant

\begin{tabular}{|c|c|c|c|c|}
\hline Nr. Crt. & Species & Experimental version & Value indicator & Significance $(p)$ \\
\hline 1. & Anthoxanthum odoratum & Martor & 45.5 & 0.3287 \\
\hline 2. & Cynosurus cristatus & Martor & 100 & $0.0372 *$ \\
\hline 3. & Trisetum flavescens & Martor & 33.3 & 1.000 \\
\hline 4. & Carex pallescens & Martor & 50 & 0.6837 \\
\hline 5. & Luzula multiflora & Martor & 37.5 & 1 \\
\hline 6. & Trifolium repens & Martor & 78.9 & $0.0372 *$ \\
\hline 7. & Vicia cracca & Martor & 33.3 & 1 \\
\hline 8. & Alchemilla vulgaris & Martor & 44.4 & 0.1810 \\
\hline 9. & Campanula patula & Martor & 37.5 & 1 \\
\hline 10. & Gentianella lutescens & Martor & 100 & $0.0372 *$ \\
\hline 11. & Gymnadenia conopsea & Martor & 37.5 & 1 \\
\hline 12. & Hieracium aurentiacum & Martor & 42.9 & 1 \\
\hline 13. & Hieracium pilosella & Martor & 100 & $0.0372 *$ \\
\hline 14. & Knautia arvensis & Martor & 60 & 0.3639 \\
\hline 15. & Leontodon autumnale & Martor & 60 & 0.3595 \\
\hline 16. & Leucanthemum vulgare & Martor & 65.2 & 0.0754 \\
\hline 17. & Pimpinella major & Martor & 41.3 & 0.6459 \\
\hline 18. & Plantago media & Martor & 62.5 & 0.1438 \\
\hline 19. & Polygala vulgaris & Martor & 37.5 & 1 \\
\hline 20. & Prunella vulgaris & Martor & 22.2 & 1 \\
\hline 21. & Rhinanthus minor & Martor & 100 & $0.0372 *$ \\
\hline 22. & Rumex acetosella & Martor & 33.3 & 1 \\
\hline 23. & Stellaria graminea & Martor & 33.3 & 1 \\
\hline 24. & Taraxacum officinale & Martor & 60 & 0.3595 \\
\hline 25. & Thymus pulegioides & Martor & 22.2 & 1 \\
\hline 26. & Tragopogon pratensis & Martor & 37.5 & 1 \\
\hline 27. & Veronica officinalis & Martor & 100 & $0.0372 *$ \\
\hline 28. & Festuca pratensis & Abandon 5 years & 33.3 & 1 \\
\hline 29. & Festuca rubra & Abandon 5 years & 39 & 0.3669 \\
\hline 30. & Lotus corniculatus & Abandon 5 years & 55.6 & 0.15 \\
\hline 31. & Trifolium pratense & Abandon 5 years & 50 & 0.1412 \\
\hline 32. & Achillea millefolium & Abandon 5 years & 48.4 & 0.1488 \\
\hline
\end{tabular}




\begin{tabular}{cllcc}
\hline 33. & Carlina acaulis & Abandon 5 years & $\mathbf{1 0 0}$ & $\mathbf{0 . 0 3 7 2}$ \\
\hline 34. & Centaurea pseudophrygia & Abandon 5 years & 38.1 & $\mathbf{0 . 3 6 5 1}$ \\
\hline 35. & Colchicum autumnale & Abandon 5 years & 55.3 & $\mathbf{0 . 0 7 2 4}$ \\
\hline 36. & Plantago lanceolata & Abandon 5 years & 37.5 & $\mathbf{0 . 8 8 8 4}$ \\
\hline 37. & Potentilla erecta & Abandon 5 years & 57 & $\mathbf{0 . 1 4 2 6}$ \\
\hline $\mathbf{3 8}$. & Trollius europaeus & Abandon 5 years & 47.4 & $\mathbf{0 . 3 5 0 7}$ \\
\hline 39. & Agrostis capillaris & Abandon 15 years & 41.4 & $\mathbf{0 . 1 7 8 6}$ \\
\hline $\mathbf{4 0 .}$ & Hypericum maculatum & Abandon 15 years & 53.2 & $\mathbf{0 . 0 7 3 6}$ \\
\hline $\mathbf{4 1 .}$ & Myosotis sylvatica & Abandon 15 years & 47.6 & $\mathbf{0 . 6 4 9 1}$ \\
\hline $\mathbf{4 2 .}$ & Ranunculus acris & Abandon 15 years & 55.6 & $\mathbf{0 . 1 4 4 8}$ \\
\hline 43. & Veronica chamaedrys & Abandon 15 years & $\mathbf{9 0 . 6}$ & $\mathbf{0 . 0 3 8 0}$ \\
\hline $\mathbf{4 4 .}$ & Viola tricolor & Abandon 15 years & $\mathbf{6 0}$ & $\mathbf{0 . 2 6 5 9}$ \\
\hline
\end{tabular}

Note: Significance: ${ }^{*}=\mathrm{p}<0.05,{ }^{* *}=\mathrm{p}<0.01,{ }^{* * *}=\mathrm{p}<0.001$

The grassland mowed annually has 6 indicator species: Cynosurus cristatus, Trifolium repens, Gentianella lutescens, Hieracium pilosella Rhinanthus minor și Veronica officinalis while the grassland abandoned for 5 years has only 1 indicator species such as Carlina acaulis. The same for grassland abandoned for 15 years which has as indicator the species Veronica chamaedrys. The presence of indicator species in each experimental variant reveals the importance of reports grouping.

As a result of the treatments applied several changes occur in the same type of grassland Festuca rubra-Agrostis capillaris (Tab. 3).

Tab. 3 Drop influence on the floristic composition

\begin{tabular}{cccc}
\hline Species & Adm martor & Adm abandon 5 years & Adm abandon 15 years \\
\hline Type meadow & $\begin{array}{c}\text { Festuca rubra- } \\
\text { Agrostis capillaris }\end{array}$ & $\begin{array}{c}\text { Festuca rubra-Agrostis } \\
\text { capillaris }\end{array}$ & $\begin{array}{c}\text { Festuca rubra-Agrostis } \\
\text { capillares }\end{array}$ \\
\hline Poaceae & & & \\
\hline Agrostis capillaries & $12.5 \%$ & $8.75 \%$ & $\mathbf{1 5 \%}$ \\
\hline Anthoxanthum odoratum & $2.5 \%$ & $1.5 \%$ & $\mathbf{1 . 5 \%}$ \\
\hline Cynosurus cristatus & $0.5 \%$ & - & - \\
\hline Festuca pratensis & - & $0.5 \%$ & $\mathbf{0 . 5 \%}$ \\
\hline Festuca rubra & $17.375 \%$ & $22.25 \%$ & $\mathbf{0 . 5 \%}$ \\
\hline Trisetum flavescens & $0.5 \%$ & $0.5 \%$ & - \\
\hline Cyperaceae and Juncaceae & & & $\mathbf{0 . 5 \%}$ \\
\hline Carex pallescens & $0.5 \%$ & $0.5 \%$ & $\mathbf{0 . 5 \%}$ \\
\hline Luzula multiflora & $0.5 \%$ & $0.5 \%$ & $\mathbf{5 \%}$ \\
\hline Fabaceae & $1.5 \%$ & & $\mathbf{0 . 5 \%}$ \\
\hline Lotus corniculatus & $1.5 \%$ & $2.5 \%$ & $\mathbf{1 . 5 \%}$ \\
\hline Trifolium pretense & $3.75 \%$ & $6.5 \%$ & $\mathbf{2 . 5 \%}$ \\
\hline Trifolium repens & $1.5 \%$ & $0.5 \%$ & $\mathbf{6 . 5 \%}$ \\
\hline Vicia cracca & $1.5 \%$ & $\mathbf{0 . 5 \%}$ \\
\hline Alte familii botanice & $10.25 \%$ & & \\
\hline Achillea millefolium & $0.5 \%$ & $3.75 \%$ & \\
\hline Alchemilla vulgaris & & $0.5 \%$ & \\
\hline Campanula patula & & & \\
\hline
\end{tabular}




\begin{tabular}{|c|c|c|c|}
\hline Centaurea pseudophrygia & $6.5 \%$ & $8 \%$ & $6.5 \%$ \\
\hline Colchicum autumnale & $1.5 \%$ & $6.5 \%$ & $3.75 \%$ \\
\hline Gentianella lutescens & $0.5 \%$ & - & - \\
\hline Gymnadenia conopsea & $0.5 \%$ & $0.5 \%$ & $0.5 \%$ \\
\hline Hieracium aurantiacum & $0.5 \%$ & $0.5 \%$ & $0.5 \%$ \\
\hline Hieracium pilosella & $0.5 \%$ & - & - \\
\hline Hypericum maculatum & $5.25 \%$ & $3.75 \%$ & $10.25 \%$ \\
\hline Knautia arvensis & $0.5 \%$ & - & $0.5 \%$ \\
\hline Leontodon autumnale & $0.5 \%$ & $0.5 \%$ & - \\
\hline Leuchantemum vulgare & $3.75 \%$ & $0.5 \%$ & $1.5 \%$ \\
\hline Myosotis sylvatica & $0.5 \%$ & $0.5 \%$ & $2.5 \%$ \\
\hline Pimpinella major & $6.5 \%$ & $6.5 \%$ & $2.75 \%$ \\
\hline Plantago lanceolata & $2.5 \%$ & $3.75 \%$ & $3.75 \%$ \\
\hline Plantago media & $2.5 \%$ & $1.5 \%$ & - \\
\hline Polygala vulgaris & $0.5 \%$ & $0.5 \%$ & $0.5 \%$ \\
\hline Potentilla erecta & $2.5 \%$ & $3.75 \%$ & $0.5 \%$ \\
\hline Prunella vulgaris & $0.5 \%$ & $0.5 \%$ & $0.5 \%$ \\
\hline Ranunculus acris & $0.5 \%$ & $1.5 \%$ & $2.5 \%$ \\
\hline Rhinanthus minor & $0.5 \%$ & - & - \\
\hline Rumex acetosella & $0.5 \%$ & $0.5 \%$ & $0.5 \%$ \\
\hline Stellaria graminea & $0.5 \%$ & $0.5 \%$ & $0.5 \%$ \\
\hline Taraxacum officinale & $0.5 \%$ & $0.5 \%$ & - \\
\hline Thymus pulegioides & $0.5 \%$ & $0.5 \%$ & $0.5 \%$ \\
\hline Tragopogon pratensis & $0.5 \%$ & $0.5 \%$ & $0.5 \%$ \\
\hline Trollius europaeus & - & $1.5 \%$ & $2.5 \%$ \\
\hline Veronica chamaedrys & $0.5 \%$ & $0.5 \%$ & $8 \%$ \\
\hline Veronica officinalis & $0.5 \%$ & - & - \\
\hline Viola tricolor & $0.5 \%$ & $0.5 \%$ & $1.5 \%$ \\
\hline
\end{tabular}

Note: Automatic Color: species that no changes compared to controls; Green: species that enhance their presence to control; Blue: species whose coverage decreases compared to the control, but do not leave even after dropping meadow phytocoenosis 15 years; Red: species that have disappeared from the grassy carpet after dropping the composition for 15 years

Therefore we observed that the species which don't show any changes compared to controls, which do not increase their presence and don't disappear from the floristic composition are: Festuca rubra, Trisetum flavescens, Luzula multiflora, Vicia cracca, Campanula patula, Gymnadenia conopsea, Hieracium aurentiacum, Knautia arvensis, Polygala vulgaris, Prunella vulgaris, Rumex acetosella, Stellaria graminea, Thymus pulegioides, Tragopogon pratensis.

The species which increase their presence compared to control variant after being abandoned for 5 and 15 years are Agrostis capillaris, Festuca pratensis, Trifolium pratense, Achillea millefolium, Centaurea pseudophrygia, Colchicum autumnale, Hypericum maculatum, Myosotis syl- vatica, Plantago lanceolata, Ranunculus acris, Trollius europaeus, Veronica chamaedrys, Viola tricolor. Species whose coverage decreases compared to the control, but do not leave the meadow phytocoenosis even after 15 years of abandonment are fewer: Anthoxanthum odoratum, Lotus corniculatus, Trifolium repens, Alchemilla vulgaris, Leuchantemum vulgare, Pimpinella major, Potentilla erecta..

Species which have disappeared from the grassy carpet after abandonment for 15 years are Cynosurus cristatus, Carex pallescens, Gentianella lutescens, Leontodon autumnale, Plantago media, Rhinanthus minor, Taraxacum officinale, Veronica officinalis. 
The floristic composition of the control variant numebers 41 species of which $33.37 \%$ Poaceae, 1\% Cyperaceae and Juncaceae, 8.25\% Fabaceae and $52.75 \%$ other botanical families. From Poaceae the dominant species is Festuca rubra $(17.37 \%)$, followed de Agrostis capillaris (17.5\%), and the other had a lower attendance. The species of the families Cyperaceae and Juncaceae are represented by Carex pallescens and Luzula multiflora low coverage of $1 \%$, the family Fabaceae is the Trifolium repens $(3.75 \%)$ and the other has a coverage of $1.5 \%$ (Lotus corniculatus, Trifolium pratense, Vicia cracca ). From other botanical families the widest coverage have species: Alchemilla vulgaris (10.25\%), followed by Centaurea pseudophrygia and Pimpinella major (6.5\%), Hypericum maculatum $(5.25 \%)$, Leuchanthemum vulgare $(3.75 \%)$ and other plants have reduced coverage.

Following abandonment knows this phytocoenosis significant changes in the floristic structure. Poaceaele increases their share with increasing the abandonment rate from $33.37 \%$ (control) to $33.5 \%$ (abandonment for 5 years) and up to $34.87 \%$ (abandonment for 15 years). Festuca rubra has a similar trend, increasing from $17.37 \%$ (control) to $22.25 \%$ (abandon for 5 years) and 15 years after dropping to $17.37 \%$ recovers. Agrostis capillaris species is reduced from $12.5 \%$ (control) to $8.75 \%$ (abandon for 5 years) after which participation increases to $15 \%$ (abandon over 5 years). Cynosurus cristatus species is the only one Poaceae, which appears only in the floristic composition of the control, after dropping 5 years and 15 years extinct.

Families Cyperaceae and Juncaceae neither increase nor reduce weight with increasing period of abandonment, except Carex pallescens species, which after abandon for 15 years disappear in the floristic composition of the grassy carpet. Fabaceae family react more strongly to the abandonment of 5 years (rising from $8.25 \%$ to $11 \%$ ), then reduce to $7.5 \%$ in Abaddon 15 years.

Among the species from other botanical families, covering species Alchemilla vulgaris, Leuchanthemum vulgare, Pimpinella major scade față de martor, but do not leave even after abandon meadow phytocoenosis 15 years: Alchemilla vulgaris: $10.25 \%$ (control)-8\% (abandon 5 years) - 6.5\% (abandon 15 years); Pimpinella major: 6.5\% (control) $-6.5 \%$ (abandon 5 years) - 2.75\% (abandon 15 years). Some species reduce their share to loss grassy carpet as: Gentianella lutescens, Hieracium pilosella, Plantago media etc.

The intensive intrusion of abandonment caused species such as grassy carpet: Festuca pratensis, Trollius europaeus.

Following the abandonment diversity is restricted from 41 species (control) 37 species (abandon 5 years) and up to 34 species for abandonment 15 years

\section{CONCLUSION}

The grassland abadnoned for 5 years didn't show any statistically changes compared to control while the grassland abandoned for 15 years registered changes in the grassy carpet, resulting in the disappearance of some species such as: Cynosurus cristatus, Carex pallescens, Gentianella lutescens, Hieracium pilosella, Plantago media etc.

Changes in vegetation structure occurred only within a single type of grassland phytocoenosis which didn't evolved to other successional stages. The results showed that abandonment is not a viable solution for maintaining grassland diversity, so semi-natural grasslands, which has many economic disadvantages because the resort is recommended to be mowed at least once in 5 years. For each type of treatment / experimental variant we had different indicator species. Therefore we reccomend the use of indicator species when we want to make a grassland management plan (APIA commitments, conservation status, etc.).

\section{REFERENCES}

1. Baur B, Cremene C, Groza G, Rakosy L, Schileyko AA (2006). Effects of abandonment of subalpine hay meadows on plant and invertebrate diversity in Transylvania, Romania. Biological Conservation, 132(2): 261-273.

2. Duffey E, Morris MG, Sheail J, Ward LK, Wells DA, Wells TCE (1974). Grassland Ecology and Wildlife Management. Chapman and Hall, London.

3. Fischer M, Wipf S (2002). Effect of low-intensity grazing on the species-rich vegetation of tradityionally mown subalpine meadow. Biol. Conserv. 104:1-111.

4. Galvanek D, Leps J (2012). The effect of management on productivity, litter accumulation and seedling recruitment in a Carpathian mountain grassland. Plant Ecol.213(3):523-533.

5. Habel JC, Dengler J, Janiskova M, Wellstein C, Wiezik M (2013). European grassland ecosystems: threatened hotspots of biodiversity. Biodivers. Conserv 22: 21312138.

6. Kryszak A, Kryszak J, Strychalska A, Klarzynska A (2012). The effect of utilization on the floristic composition of 
meadow communities. Journal of Life Sciences 6:10611067.

7. Marușca T (2012). Appeals to tradition village. Publisher Transilvania University of Brasov.

8. McCune B, Grace J (2002). Analysis of Ecological Communities. Printed in the USA.

9. McCune B, Mefford M (2011). PC-ORD. Multivariate Analysis of Ecological data. Versiunea 6. MjM Software, Gleneden Beach, Oregon, U.S.A.
10. Osterburg B, Isermeyer F, Lassen B, Röder N (2010). Impact of economic and political drivers on grassland use in the EU. Grassland science in Europe 15: 14-28.

11. Păcurar F, Rotar I (2011). Ecopratologie. Curs.

12. Păcurar F, Rotar I (2014). Metode de studiu și interpretare a vegetației pajiștilor. Editura Risoprint, Cluj-Napoca.

13. Tasser E, Tappeiner U (2002). Impact of land use changes on mountain vegetation. Applied Vegetation Science. 